\title{
Nowhere countries: When states use extra-territoriality at home to circumvent legal, human and refugee rights
}

Pauline Maillet

\section{Introduction}

The opening statement of the Maastricht Principles laments the fact that, 'despite the universality of human rights, many states still interpret their human rights obligations as being applicable only within their own borders'. Concurring with the Maastricht Principles' observation, this chapter discusses how two states have redrawn their borders in order to escape or lessen their legal, human and refugee rights obligations. Contrary to the other contributors, I am concerned with the protection that states owe to individuals located within their geographical boundaries, on pieces of land declared extra-national. I use the term 'extra-territoriality' (with a hyphen) to refer to exclusionary practices taking place within states' territories. More precisely, this term refers to the designation, by a state, of a piece of its territory as 'not national territory', for certain categories of people: non-citizens depicted as undesirable. The term 'nowhere countries', coined by French activists, aptly describes these spaces deemed extra-territorial for non-citizens categorized as undesirable. Nowhere countries can be established and thrive on any part of a state territory, but international zones at airports and islands have been spaces of choice for these zones of exclusion. Nowhere countries have been used by some states to curtail access to domestic legal rights as well as access to human and refugee rights granted by international law. While the other contributors to this volume explore the duties of states outside of their territorial boundaries, this chapter reaffirms states' obligations to individuals located within their territories, in places labelled extra-territorial.

Drawing from the French and the Canadian cases, I argue that exclusion from rights through extra-territoriality may take two main forms. Under the first configuration of extra-territoriality, state authorities consider non-citizens to be not physically located on the state's territory. Exclusion from rights is triggered by geography and legal absence: situated in a geographical space construed as non-national, some incoming people are denied access to the legal, human and refugee rights attached to sovereign territory. Under this first configuration, the non-citizens in question are placed in a legal limbo: they are left outside of applicable legal frameworks, both at the domestic and international levels. This is what happened to non-citizens stranded in the 
international zone at Paris' airports in France in the 1980s and early 1990s: the government instructed border authorities to disregard the applicable domestic legal framework and its associated rights. Foreign nationals were refused the protection of the law on account of their location in a space portrayed as extra-territorial. Similarly, people from the Fujian Province who arrived off the Canadian coast of British Columbia in 1999 were taken to the Esquimalt naval base on Vancouver Island, a place depicted as 'Not-Canada' (Mountz 2010). Canadian authorities declared the naval base a 'port of entry' claiming that the Chinese people were still walking the tunnels of an international airport, not yet landed in Canada. This trick allowed the Canadian government to deny access to lawyers during processing at the base: migrants being assessed at a port of entry did not have the right to legal counsel under Canadian law. This first configuration of extraterritoriality attracted widespread criticism from human and refugee rights activists, lawyers and courts, and may have forced states to resort to a subtler configuration.

The second form of extra-territoriality (the second and the first form not being mutually exclusive) is less manifest: when physically located in spaces deemed extra-territorial, noncitizens are not refused legal protection. Instead, they are subjected to a less protective regime compared to that granted to foreign nationals who are not located in spaces construed as extranational. Exclusion from the regular rights regime is triggered by geography and a legal technique. Although non-citizens receive the exclusionary status when located in a space declared extra-territorial, the exclusionary regime follows them well after they leave this space. Once non-citizens are assigned to the French legal regime of exclusion, they carry it with them wherever they go. The waiting zone has created a particular legal space of lesser rights that always accompanies the individual, no matter his or her location. Practitioners explain that non-citizens carry the waiting zone status like a 'backpack' or are in a waiting zone 'bubble'.

Importantly, alternate legal regimes may be enshrined in the law or exist de facto, as evidenced by the Canadian case. The Chinese boat people's location on Esquimalt naval base, a space declared extra-territorial, triggered a less protective legal regime that was not engraved in Canadian law. While the asylum seekers were granted due process on paper, in practice their access to rights was altered by their passage through a place considered as 'Not-Canada'. The second form of exclusion from rights through extra-territoriality allows states to appear engaged in the global refugee regime while subverting it. Both configurations of extra-territoriality enable states to tailor the border to suit their immigration goals and to evade their obligations under the Refugee Convention. While the state practices hereby described are not limited to France and Canada, this chapter will only be able to cover that of the two aforementioned states.

\section{First configuration of extra-territoriality at home: Exclusion from rights through geography and a legal absence}

\section{The case of the international zone at French airports in the 1980s and 1990s}

International airports are interesting sites where legal and cartographic borders do not map onto one another (Lochak 1992). There, borders are created at the heart of states' territories, without a territorial delimitation between states. This creation of borders ex nihilo, or what Del Valle Galvez (2005) refers to as the 'legal fiction of the interior border', is permissible under international law, as there is no human right to enter a country, except one's own. The admission of an individual to a country is a state's discretionary act. However, as Del Valle Galvez (2005) explains, this 'legal fiction of the interior border' can easily lead to an 'extra-territorial legal fiction' (hyphen added). France implemented this extra-territorial legal fiction in the 1980s and 
early 1990s. The French government considered individuals in international zones to be not on French territory for they had not gone through police control and customs. Thus, France transformed the legal distinction between de facto entry and formal entry (that characterizes the "legal fiction of the interior border') into the dichotomy formal entry/no formal entry.

At the time, the status of the international zone, also called 'transit zone', was not well defined. International law did not explicitly state whether or not transit zones were part of a state's territory or what laws applied to passengers located in these spaces. Originally, Annex 9 to the Chicago Convention's definition of a 'direct transit area' (First edition, 1950) did not include passengers. At first, it was 'a special area established in connection with an international airport, approved by the public authorities concerned and under their direct supervision for accommodation of traffic which is pausing briefly in its passage through the Contracting state'. In 2004 the Facilitation Division of the International Civil Aviation Organization proposed to broaden this definition to mention that 'passengers can stay during transit or transfer without being submitted to border control' in the direct transit area (FAL/12-WP/6, 12/11/03). This international legal instrument did not, and still does not, specify the perimeter of the direct transit area. It became apparent in 1993, at a conference gathering lawyers and activists from Europe and North America, that countries delineated airport transit zones' perimeter differently (Anafé 1993). This lack of consensus allowed the French government to claim that the international zone included hotels.

Nevertheless, it does not mean that airports' transit zones were not covered by international law in the 1980s. As previously mentioned, Annex 9 to the Chicago Convention established that the transit zone was directly supervised or controlled by the public authorities of the state concerned. This meant that the state in question exercised its territorial sovereignty over the transit zone. As Labayle (1993, p. 48) explains, a state exercising its sovereignty over a territory is competent both to create and implement rules. As soon as international legal scholars, international human rights courts and treaty monitoring bodies turned to the matter of the international or transit zone, they clearly stated that this space was integrally part of the state's territory. Under international law, airports' transit zones are not extra-territorial spaces.

In the years preceding the Law on the Waiting Zone (July 6, 1992), French law provided for the detention of non-citizens turned away at the border and equipped them with legal safeguards. The 1945 Ordinance (art. 35 bis) allowed detention of non-admitted individuals in administrative facilities for a maximum of seven days - time period deemed necessary for them to be returned. However, detention was to take place 'in case of absolute necessity' during 'the time strictly necessary for the departure' of the foreign national. While the decision to detain was taken by an administrative agent, detainees had to be presented to a liberty and custody judge after 24 hours. On an exceptional basis, the judge could extend the duration of detention to six more days, bringing the maximum amount of time spent in confinement to seven days in total. After this time, if return had not occurred, the non-citizen had to be set free. The judge's decision could be appealed and the public prosecutor (immediately informed of the detention decision) always had the possibility of checking detention conditions. Important rights were attached to Article 35 bis, including the rights to see a doctor and a counsel and to communicate with the consulate or any person of the detainee's choosing. Non-French speakers had to be notified of the aforementioned rights by an interpreter.

Claiming that international zones were extra-national spaces allowed the French government to circumvent domestic and international laws. According to the newspaper Le Monde (Bernard 1992), 10,000 travellers per year were denied entry into France due to missing or improper travel documents. Less than $1 \%$ of these travellers were placed in administrative detention under the legal rules applicable at the time. Therefore, in the 1980s and the early 1990s, the bulk of 
the non-citizens rejected at the border were held in the international zone in a legal vacuum. Detention outside of the 1945 Ordinance allowed the border police to keep non-admitted foreign nationals for more than seven days and, generally, to deny them the safeguards provided by Article 35 bis of the same Ordinance. Rejected passengers were left outside of the protective reach of domestic laws.

As far as asylum seekers were concerned, French legislation did not permit their detention. Indeed, the 1945 Ordinance authorized detention only once a non-admission decision was made, not before. At the time, a decree (May 27, 1982) stated that only the Ministry of the Interior could decide to deny entry to asylum seekers, after consulting with the Ministry of Foreign Affairs. From September 1991 refugee agency representatives were delegated to the borders to hear claimants and advise the Ministry of Foreign Affairs before it offered its opinion to the Ministry of the Interior (Lochak 1992, p. 680). Importantly, France was already a party to the 1951 Refugee Convention and to its 1967 Protocol. As such, the French state had to honour its nonrefoulement obligation and could not impose criminal sanctions against refugees for illegal entry (respectively arts. 33 and 31 of the Refugee Convention). The duty of non-refoulement is the cornerstone of refugee law: it "prohibits states from exposing a refugee "in any manner whatsoever" to the risk of being persecuted for a Convention reason' (Hathaway and Gammeltoft-Hansen 2015 , p. 238). Domestic legislation acknowledged the obligation to take international conventions into account in entry decisions (1945 Ordinance, art. 5). Under domestic and international law, asylum seekers could not be denied entry for lack of travel documents. They could only be refused access for security reasons, under Article 5 of the 1945 Ordinance: threat to the public order, previous banishment from territory or deportation order.

In practice, those seeking international protection could be confined for days or weeks in the international zone while the refugee agency, the Ministry of Foreign Affairs and the Ministry of the Interior decided on their cases. Some claimants also experienced refoulement. To justify these practices, the French government argued that the international zone had extra-territorial status. As explained by Hoop de Scheffer, Council of Europe rapporteur, who visited Roissy-Charles de Gaulle (CDG) Airport on November 20, 1989:

Asylum-seekers are detained in a so-called international zone at the airport, which means that they are not yet on French territory and the French authorities are therefore not under a legal obligation to examine the request as they would be if a request was made by someone already on French territory. The international zone has no legal background and must be considered as a device to avoid obligations [...]. No legal basis for detention exists and a maximum term is not prescribed by law.

(Lord Mackie of Benshie 1991, p. 7)

French authorities at Charles de Gaulle Airport assumed that they were under no legal obligation to examine asylum seekers' requests in international zones, on the basis that they were not on French territory yet. While French authorities insisted that the duration of detention was limited to a week, some asylum claimants told the Council of Europe Rapporteur that they had been waiting for six weeks in the international zone (Lord Mackie of Benshie 1991, p. 7).

Those denied admission or waiting on an admission decision at French airport borders were detained in small holding rooms in the airport's international zone and/or in nearby hotels, which were construed as an extension of the international zone. The employees working for Paris' Airports or airline companies were tasked with guarding the non-citizens in holding rooms. Distressed by the plight of detainees, trade unionists contacted lawyers and NGOs defending human and foreign nationals' rights. 
Activist lawyers started to sue the Ministry of the Interior from 1988 for arbitrary detention of foreign nationals in the international zone. Lawyers coined the term 'legal fiction' to debunk the government's extra-territorial theory according to which non-nationals present in the international zone were deemed outside of France (interview with Serge Slama, law professor, Paris, July 2014). It is not a legal term and therefore cannot be found in legal textbooks (interview with Danièle Lochak, law professor, Paris, July 2014). Activist lawyers using the term 'legal fiction' did not define it. According to the Oxford online English dictionary (accessed December $7,2014)$, a fiction is 'an invention or fabrication as opposed to fact'. The expression 'legal fiction' was precisely meant to convey the idea that the government fabricated the international zone as a lawless area. Activists found it useful to denounce the exclusion of individuals located in the international zone from the guarantees offered by French law and international human rights and refugee law.

The lawyers' goal was to obtain a ruling that would release the asylum seekers in question from the international zone on the grounds that detention in this space was tantamount to arbitrary sequestration and therefore resulted in severe infringement upon a fundamental liberty (Lochak 1992, p. 682). The judge who heard the cases had a limited mandate: putting a stop to an illegal administrative practice resulting in a severe violation of fundamental rights. The judge could therefore only order the government to put an end to confinement in the international zone. Until November 1991, these trials did not affect the government, which always instructed border authorities to return or admit to the territory the foreign national in question before the hearing took place.

The newspaper Le Monde, dated November 21, 1989, described one of these trials (Peyrot 1989). Isabelle arrived at Charles De Gaulle from then Zaire on November 4, 1989. She had fled her country where she had been imprisoned, beaten and raped by soldiers on account of her religious opinions. In spite of presenting a regular passport, visa and financial means, she was denied entry at the border and detained at the Arcade hotel at Charles De Gaulle Airport. Her counsel, Bourguet, paid her a visit on November 11 and immediately forwarded a refugee status request to the refugee agency. As his client remained deprived of liberty, Bourguet sued the Ministry of the Interior before the Paris Court of First Instance. He pleaded that his client's arbitrary detention had severely infringed upon her fundamental rights. However, the judge could not rule on 'a situation that had ended', as Isabelle had been released just before the hearing. The newspaper notes that the government had already resorted to the same manoeuvre several times. The Ministry of the Interior had consistently made sure that the non-citizen was no longer held in the international zone at the date of the hearing. Since the foreign national had either been sent back to the country of departure or admitted to French territory, the point of contention had disappeared (Bourguet 1992). Therefore, the judge had no other option but to declare that he lacked jurisdiction. This strategy on the part of the government endured for a few years after Isabelle's case.

The situation finally changed when the Paris Court of First Instance issued a very unusual ruling. On November 22, 1991, the Court allowed a Haitian asylum seeker to sue the Ministry of the Interior for 'arbitrary sequestration' and monetary compensation even though he had been admitted to France in the meantime. The plaintiff had landed in Charles De Gaulle on November 6, 1991 where he had been refused entry. He had been confined for two days in the international zone and six days at the Arcade Hotel. He had been informed that he was to be put in the next available plane to Port-au-Prince. The court hearing took place on February 26, 1992 and also dealt with the similar cases of four other asylum seekers (three Haitians and one Zairian) who had landed in Charles de Gaulle Airport on November 19, 1991 (Bernard 1992). Their lawyers had also been authorized by the same Court of First Instance on November 26, 
1991 to pursue the cases on their merits. At the hearing, the Ministry of the Interior acknowledged the following: their deprivation of liberty was not based on any legal document, a legal framework existed but was not applied, and lastly, the order was expressly given to civil servants not to detain foreign nationals at the border under the existing legal framework (Paris Court of First Instance 1992a).

The hearing revealed that the plaintiffs' right to seek asylum had been violated. France did not uphold its non-refoulement obligation, as decisions were made to return the asylum seekers in question to Kinshasa and Port-au-Prince. Their return was stopped in extremis when the Court heard their case. The asylum seekers also faced obstacles when filing their claim: only two plaintiffs could have their claim registered while the other two were treated as regular migrants failing to fulfil entry conditions.

The Court ruled on March 25 (Paris Court of First Instance 1992b), rejecting the government's extra-territoriality thesis. It found that there was no domestic or international document giving extra-territorial status to all or part of the Arcade hotel where asylum seekers had been held. The Court agreed that the international zone constituted a 'legal fiction' and ruled that holding at the Arcade hotel constituted a deprivation of liberty.

What would become the landmark European Court of Human Rights case, Amuur v. France (ECtHR 1996), started at the domestic level the following day, on March 26, 1992, when lawyers Dominique Monget-Sarrail, Laurence Roques and Pascale Taelman first brought the case to the Créteil Court of First Instance. As previously stated, the day before the Paris Court of First Instance had rejected the government's extra-territoriality thesis, according to which the government argued that the Arcade hotel at Charles De Gaulle Airport was part of the international zone and, as such, had extra-territorial status. The Amuur case was part of a series of trials that activist lawyers launched against the French government from the late 1980s.

Four Somali siblings arrived on March 9, 1992 at Paris Orly Airport from Syria where they had spent two months after fleeing from Somalia via Kenya. They alleged their lives were at risk in Somalia after the fall of President Siyad Barre. The border police refused them entry on the basis that their passports were forged. They were placed at the Arcade hotel, which was considered an extension of the international zone. On March 12, the Ministry of the Interior examined their request to enter France to claim asylum. By March 14, 18 other Somali nationals (among which 11 children) had arrived at Orly from Syria and Egypt. Of these 18 Somali citizens, 5 were cousins of the Amuur brothers and sister. They were all members of the Darob Marhan tribe, which was in power during the regime of President Mohamed Siyad Barre. They explained that several members of their family had been murdered. After obtaining legal aid, they wrote a letter to the refugee agency on March 25, requesting refugee status according to the Geneva Convention of 1951. On March 26, their case was referred to the Court of First Instance at Créteil on the grounds that their deprivation of liberty was arbitrary. Lawyers Monget-Sarrail, Roques and Taelman transferred the case of the 22 plaintiffs to the European Commission of Human Rights on March 27, 1992.

The European Commission of Human Rights then referred the case of the four Amuur siblings to the European Court on March 1, 1995. The plaintiffs had argued that several articles of the European Convention on Human Rights had been violated (arts. 3, 4, 5, 6, 13 and 25), but the Commission rejected all of the alleged violations save the one based on Article 5 (right to liberty and security). In its observations to the European Commission (transmitted on July 7, 1992), the French government claimed that the plaintiffs' 'holding' (maintien) in the international zone did not amount to deprivation of liberty: they were not arrested or detained. They were instead 'staying' (séjourner) in the international zone as they were free to leave for any other destination than France (Council of Europe: European Commission of Human Rights, October 18, 1993). 
The European Court of Human Rights (ECtHR 1996) rejected this claim and concluded that the applicants had indeed suffered a deprivation of liberty in the international zone. Their detention was found to be unlawful as it had had no legal basis in domestic law: France was declared to have violated Article 5 by illegally depriving the Somali asylum claimants of liberty. As the court explicitly stated, 'despite its name, the international zone does not have extraterritorial status'. The court remarked that the French Constitutional Council had not challenged 'the legislature's rights to lay down rules governing the holding of aliens in that zone'. In other words, the court observed that France exercised jurisdiction over the international zone at Orly Airport. This is how a manual of International Law (Shaw 2017) defines jurisdiction:

Jurisdiction concerns the power of the state under international law to regulate or otherwise impact upon people, property and circumstances and reflects the basic principles of state sovereignty, equality of states and non-interference in domestic affairs. Jurisdiction is a central feature of state sovereignty, for it is an exercise of authority which may alter or create or terminate legal relationships and obligations. It may be achieved by means of legislative, executive or judicial action.

The case of Amuur v. France illustrates the fact that a state cannot decide to exercise jurisdiction selectively; laws must apply homogeneously to all individuals under jurisdiction. As jurisdiction cannot be withdrawn at will, the non-citizens in the international zone at Orly Airport were subjected to French law, even though French authorities claimed the opposite. Manipulations of jurisdiction are not valid under international law, and, therefore, states cannot evade their obligations by labelling a piece of their territories 'extra-territorial'.

Yet, just a few years after the Amuur v. France ruling was passed, another state resorted to such an extra-territorial legal fiction to deprive non-citizens of rights. Interestingly, the Canadian government used the arguments developed by the French government (i.e. the idea that the international zone at airports was an extra-territorial space).

\section{The case of the Esquimalt Naval Base in Canada in 1999}

Mountz (2010) pursued research with the Department of Citizenship and Immigration Canada (CIC) in the wake of the interceptions of 599 individuals from China off the coast of British Columbia in July 1999 by Canadian authorities. She documented how the Canadian authorities developed the 'long tunnel thesis' to claim that the Chinese people placed at the Esquimalt naval base had not reached Canadian soil yet, in spite of them being physically located on Canadian territory.

The non-citizens, who had been smuggled, arrived in four different boats over the course of six weeks (Mountz 2010). At the time, tens of thousands of smuggled non-citizens were arriving at Canadian airports every year, making this figure of 599 individuals rather unremarkable. Yet, the non-citizens from the Fujian Province were treated differently compared to those arriving by land or air. Their boats were towed, and they were taken by ship or by bus to the Esquimalt naval base on Vancouver Island, which was declared a 'port of entry'.

At the naval base, the non-citizens were considered inside the tunnels of an international airport, not yet landed in Canada. The construction of the Esquimalt naval base as 'Not-Canada' carried deep implications for the boat people's access to rights. Firstly, like in French airports in the 1980s, the non-citizens were denied access to rights. During processing at the base, they were refused access to lawyers. Indeed, the CIC, the federal agency in charge of managing immigration, refugee claims and border enforcement, wanted to gather as much information as possible about the boat people's journeys and their smugglers before allowing lawyer access. 
CIC was wary of lawyers, as they might have advised their clients to claim refugee status and to present their stories accordingly. In order to delay access to lawyers, the Canadian government temporarily designated the Esquimalt base as a port of entry. This designation carried important consequences, since migrants in detention did have the right to legal counsel under Canadian law, whereas migrants being processed at a port of entry did not. Lawyers observed that the Chinese people were undeniably detained, as evidenced by the presence of barbed wire, guard dogs and guards on the military base. Some individuals spent up to 14 days at the Work Point Barracks at Esquimalt, in 'processing'. During this time, immigration officials conducted preliminary interviews with the non-citizens with no legal counsel being present. The Canadian and the French case are very similar in the sense that both states resorted to the two configurations of extra-territoriality to exclude non-citizens from rights. After refusing to treat the non-citizens according to the laws in force at the time of their arrival, Canadian and French authorities placed them under less protective legal regimes (these alternate legal regimes are either enshrined in law or exist de facto).

\section{Second configuration of extra-territoriality at home: Exclusion from rights through geography and an alternate legal regime}

\section{The French waiting zone from July 6, 1992 to nowadays}

The ruling issued by the Paris Court of First Instance on November 22, 1991 apparently unnerved the French Ministry of the Interior. The court had allowed the Haitian asylum seeker to sue the Ministry of the Interior for 'arbitrary sequestration' and monetary compensation, even though he had been admitted to France in the meantime. Faced with challenging upcoming litigation, Philippe Marchand, the Socialist Minister of the Interior at the time, decided to draft a legal provision addressing the situation of non-admitted foreign nationals and asylum seekers in the international zone, which he renamed 'transit zone'. This provision on the transit zone finally came into being through the Law on the Waiting Zone of July 6, 1992.

Non-citizens in the international zone ceased to be detained in a legal void as of July 6,1992, when the Law on the Waiting Zone was finally passed. The Socialist government presented this new legislation as significant progress: France was setting a fine example in terms of rights protection. Yet, the Law on the Waiting Zone offered a less advantageous legal framework to non-citizens compared to the one previously in place that the government had refused to apply (i.e. 1945 Ordinance, art. 35 bis). Under this new law, detainees were to be presented to a judge after four days in the waiting zone (compared to one day previously) and could not spend more than 20 days in the waiting zone (confinement was limited to seven days previously).

Furthermore, the Law on the Waiting Zone established a parallel and less protective system of rights based on the distinction between physical and legal entry. Before the Law on the Waiting Zone came into existence, the same legislative provisions applied to all foreign nationals detained for immigration control purposes: the law did not establish any distinction between those at French borders and those already deemed to be on French territory. Non-citizens all benefited from the same rights. This equality before the law ended in 1992, with the Law on the Waiting Zone. Since this time, non-citizens arriving at the border have been subjected to a watereddown legal framework compared to the one applicable to those already deemed to be on French soil (who are either applying for asylum or are to be removed after staying illegally in the country). This less advantageous legal regime was precisely premised on the idea that international zones, renamed 'transit zones' and then 'waiting zones', were somehow extra-territorial spaces. 
When the Law on the Waiting Zone came into force in July 1992, the overt mechanisms of exclusion shifted in the sense that the law itself (and not the absence thereof) created a less protective regime than that applicable to the same groups regarded as being on French territory. Exclusion, in other words, was reinvented: instead of individuals being placed outside of the law, the law itself organized exclusion. The waiting zone's exclusionary legal framework builds on the premise that groups at the border find themselves from a legal standpoint at the threshold of, but not yet having entered, French sovereign territory. They find themselves, instead, in territorial border zones where the state establishes the distinction between physical and legal entry: physical presence proves insufficient and only lawful admission amounts to entry into the territory (Basaran 2011). In the 1980s, exclusion was triggered by geography and legal absence: it started from the moment the non-citizen set foot in the geographical location of airports' international zones. Today, under the Law on the Waiting Zone, exclusion is triggered by a combination of geography and law: an individual is placed under the waiting zone framework when arriving in the border's physical location and after being refused entry or registered as an asylum seeker. Although physically in France, rejected non-citizens and asylum seekers at the border are not present from a legal standpoint, for they have not crossed yet 'law's admission gate' (Shachar 2007).

The Law on the Waiting Zone governs foreign nationals denied admission into French or Schengen territory or claiming asylum at a French border arriving by train, boat or airplane (CESEDA 2016, arts. L221-1 to L224-4). Those assigned the waiting zone status are detained during the time necessary for them to be returned or, if they are claiming asylum, to determine whether or not their claim is inadmissible or 'manifestly unfounded'. Individuals located in the waiting zone are not governed by ordinary laws, but instead subjected to its particular legal regime. Two groups particularly suffer from the eroded rights attached to the waiting zone status: asylum seekers and minors (especially when unaccompanied). Indeed, the regular refugee determination procedures do not apply to asylum seekers at the border. Only asylum seekers passing through this initial sieve will be entitled to enter French territory where claims will be examined on their merits. The number of claimants able to file a claim has varied greatly over the years. In 2011, the French refugee agency (OFPRA) reviewed the case of 1857 claimants (for all waiting zones) and recommended that 188 be admitted to the territory: about $10 \%$ of claimants got access to refugee status determination (OFPRA 2012). In 2012, this number was 13.1\% (OFPRA 2013) but increased to 40.5\% in 2019 (OFPRA 2020). As for unaccompanied minors, they are denied due process rights that children in France enjoy (HRW 2014). All unaccompanied minors who are not asylum claimants are detained in waiting zones. As for those seeking asylum, the law provides for their detention in waiting zones under many circumstances (Maillet 2019).

Since July 1992, the scope of the Law on the Waiting zone has been extended significantly, following litigation 'crises'. At first, those denied entry or seeking asylum were geographically circumscribed by an administrative authority (le préfet) to waiting zones, which ran between points of boarding or disembarkation and border checkpoints. These zones could include accommodation located on or nearby the airport, port or train station. When the Law on the Waiting Zone was first passed in July 1992, it read that the waiting zone 'runs between the points of embarkation and disembarkation to the border checkpoints', therefore covering the area of the 'international zone'. The law also specified that the waiting zone could include nearby hotellike accommodations. The geographical space of the waiting zone therefore mapped onto that of the international zone and onto what the government construed as its extension, i.e. hotels close by. The perimeter of the waiting zone is now larger than that of the international zone, as it encompasses any place where the person goes for administrative or medical reasons. As a result, the waiting zone status now accompanies the individual, even kilometres from the point 
of arrival. Trapped by the waiting zone framework, foreign nationals 'are not expelled by the border, they are forced to be the border' (Khosravi 2010, p. 99). In the French case, the legal regime of the waiting zone has been engraved in law. The Canadian case shows us that these alternate legal regimes providing individuals subjected to them with diminished protection can also exist de facto.

\section{The Canadian de facto alternate legal regime in 1999}

In Canada, on Vancouver Island, the non-citizens' location in a space declared extra-territorial triggered a less protective legal regime. On paper, the Chinese non-citizens were accorded the regular protection of the law. After processing, 500 of the 599 non-citizens asked for refugee status. The asylum seekers were granted due process under the Canadian Charter of Rights and Freedoms: their cases were heard, and they could exhaust all appeals procedures. However, in practice, they experienced diminished protection. While claimants from the first boat were released after processing on Vancouver Island, those from the second, third and fourth boats were detained. At the time, detention of non-citizens in Canada for immigration purposes was quite rare. Many claimants from the first boat did not attend their refugee hearings; they were considered to have left Canada to work in Chinatown in New York City. Yet, as Mountz (2010, p. 77) notes, the fact that many boat people absconded did not justify the massive use of detention. After all, many non-citizens entering Canada by air or land also vanished after their release:

The reasons this group was treated differently through detention en masse went largely unexplained. Officials cited the involvement of organized crime, the failure of claimants to provide identity documents and the fact that they were likely to flee. The same could be said, however, of many arriving at airports and land borders who were released during the same time period.

Claimants from the second, third and fourth boats were detained in a provincial prison in the small city of Prince George, in the interior of the British Columbia Province. In this remote location, that stood ten hours away by car from Vancouver, the claimants experienced isolation from refugee lawyers, interpreters, human rights monitors and the Chinese community. Their cases were heard inside the prison, in provisional tribunals, and adjudicated by Immigration and Refugee Board officers especially brought to the prison. The claimants attended their hearings wearing prison outfit and handcuffs. Refugee lawyers and advocates argued that the claimants had not benefited from the regular rights regime, as the government used the data that was obtained in the absence of legal counsel at the military base to point to contradictions in the claimants' stories. Lawyers also deplored the fact that claimants were not identified and treated as individuals but as a homogeneous group. Furthermore, refugee advocates argued that Immigration and Refugee Board members, who were temporarily accommodated in Prince George, were in a hurry to decide on the cases, as they were keen on returning home.

Almost all of the claims that were heard in Prince George were ultimately rejected. Only 24 asylum seekers had their claims accepted out of the 577 claimants. At the time, asylum seekers from China had a 58\% approval rate. By contrast, the approval rate dropped to less than $5 \%$ for the claimants who arrived by boat in 1999. The majority of those who were conferred refugee status had not been detained in the regular criminal system in Prince George but had been hosted or detained in the surroundings of Vancouver in youth facilities or prisons. There, they enjoyed access to experienced refugee lawyers, and their claims were heard in a more individualized manner at the regional headquarters of Citizenship and Immigration Canada. Claimants 
that were detained in Prince George did not enjoy the same quality of access to the refugee determination process. One lawyer argued that they experienced 'skeletal justice', by opposition to the 'thick justice' taking place in Vancouver. Many of the claimants who had been detained were deported back to China in 2000 after they exhausted all legal recourses. The media, public opinion and the government depicted the asylum claimants as illegal migrants trying to abuse Canada's generous refugee system. The inscription of the 'bogus refugee' identity to the Chinese claimants triggered their detention in 'Not-Canada' and in the remote location of Prince Georges as well as the subsequent subversion of the access to the regular rights' regime. As Mountz (2010, p. 113) puts it: 'the narrative of who these migrants were explains where they were located and vice versa'.

\section{Conclusion}

To conclude, states have created 'nowhere countries' at the very heart of their territories. In other words, they have engaged in elaborate manoeuvres to redraw their territorial boundaries, in the hope of selectively relinquishing jurisdiction over some parts of their territories. The very fact that states have gone to such lengths to manipulate their borders suggests that they still entertain a very territorial conception of their rights obligations - as if the assignment of an 'extra-territorial' character to some parts of their land magically lifted or diminished the protection owed to individuals thereby located. Yet, 'nowhere countries' do not exist under international law. Despite states' efforts to practice what could be called 'selective sovereignty', islands and international zones at airports are all part of the state's territory. This is a fact that cannot be changed by domestic law (Hathaway 2005). States' obligations towards all individuals falling within their jurisdiction must be urgently reiterated.

\section{References}

Anafé (1993) Frontières du droit, frontières des droits: l'introuvable statut de la 'zone internationale', L'Harmattan. Basaran, T. (2011) Security, Law and Borders: At the Limits of Liberties, Routledge.

Bernard, P. (January 21, 1992) " "L'amendement Marchand" à nouveau devant les parlementaires. Des demandeurs d'asile contestent la "zone internationale" prévue par le Ministère de l'Intérieur', Le Monde.

Bourguet, C. (1992) "La notion de frontière dans les aéroports ou 'le pays de nulle part'. Autres Temps. Les cahiers du christianisme social. 33-34, 24-31.

DelValle Galvez,A. (2005) 'Las zonas internacionales o zonas de tránsito de los aeropuertos, ficción liminar fronteriza', Revista Electrónica de estudios internacionales 9, 1-18.

European Court of Human Rights (ECtHR) (1996) Amuur v. France, Application no: 19776/92, Judgment. French Office for the Protection of Refugees and Stateless people (OFPRA) (2012) Rapport d'activité 2011.

(2013) Rapport d'activité 2012.

(2020) Rapport d'activité 2019.

Hathaway, J.C. (2005) The Rights of Refugees Under International Law, Cambridge University Press.

Hathaway, J.C. and Gammeltoft-Hansen T. (2015) 'Non Refoulement in a World of Cooperative Deterrence', Columbia Journal of Transnational Law 53(2), 235-284.

Human Rights Watch (HRW) (2014) France: Unaccompanied Children Detained at Borders. 500 a Year Held in Transit Zones.

International Civil Aviation Organization (ICAO) (1944) Convention on International Civil Aviation ('Chicago Convention').

(2003) Facilitation Division, Twelfth Session, FAL/12-WP/6, 12/11/03.

(2005) Annex 9 to the Convention on International Civil Aviation, 12th edition, July 2005. 


\section{Pauline Maillet}

Khosravi, S. (2010) 'Illegal' Traveller: An Auto-Ethnography of Borders, Palgrave Macmillan.

Labayle, H. (1993) 'Réglementation et souveraineté des Etats' in Anafé (ed.). Frontières du droit, frontières des droits: l'introuvable statut de la 'zone internationale', L'Harmattan.

Lochak, D. (1992) 'Bulletin de jurisprudence française', Journal du droit international.

Lord Mackie of Benshie (1991) Report on the arrival of asylum seekers at European airports, Report N 6490, Parliamentary Assembly of the Council of Europe.

Maillet, P. (2019) Nowhere Countries: Exclusion of Non-Citizens from Rights Through Extra-Territoriality at Home, Brill Nijhoff.

Mountz, A. (2010) Seeking Asylum: Human Smuggling and Bureaucracy at the Border, University of Minnesota Press.

Paris Court of First Instance (1992a) First Chamber, Hearing. (1992b) Ruling.

Peyrot, M. (November 21, 1989) 'La situation juridique de la zone internationale de l'aéroport de Roissy. Prisonnière au pays de nulle part', Le Monde.

Shachar, A. (2007) 'The Shifting Border of Immigration Regulation', Stanford Journal of Civil Rights and Civil Liberties 3(2), 165-193.

Shaw, M. (2017) International Law, Cambridge University Press.

UN General Assembly (1951) Convention Relating to the Status of Refugees. (1967) Protocol Relating to the Status of Refugees. 